\title{
Aplikasi Media Simulasi Virtual pada Model Pembelajaran ECIRR untuk Meremediasi Miskonsepsi Siswa pada Materi Perubahan Wujud Zat
}

\author{
Sanny S Silaban ${ }^{1}$, Andi Suhandi ${ }^{2}$, Yohanes Edi Gunanto ${ }^{3}$ \\ ${ }^{1,3}$ Pendidikan Fisika, Fakultas Ilmu Pendidikan, Universitas Pelita Harapan, Karawaci, Tangerang. \\ ${ }^{2}$ Sekolah Pascasarjana, Universitas Pendidikan Indonesia, Isola Sukasari, Bandung. \\ Email : 1) sanny.silaban@uph.edu, 2) a_bakrie@yahoo.com, ${ }^{3)}$ yohannes.gunanto@uph.edu
}

\begin{abstract}
The purpose of this research is to get the description about the effect of virtual simulation media application on ECIRR (Elicit, Confront, Identify, Resolve, Reinforce) learning model to remediate high school student's misconception about Change of Matter. Virtual simulation media then used to visualize microscopies phenomena for Change of Matter in which it cannot be observed directly by the naked eye. Virtual simulation media was integrated on Resolve phase in order to remediating student's misconception. Mix method qualitative-quantitative was used by involving 38 second-year students at one of Senior High School in West Bandung Regency with one-group pretestposttest design. The sample is determined by purposive sampling, with the criteria used as a sample are students who have misconception on the Change of matter. Misconceptions and changes in student conceptions are diagnosed using diagnostic tests of misconception of three-tier test. This research focuses on four misconceptions found in students labeled M1, M2, M3 and M4. The average quantity of students who misconception on pretest does not reach $50 \%$ in each misconception label, while the rest are scattered in other categories, such as $12 \%$ Scientific knowledge, 26\% Lack of knowledge, 9\% Error, and 30\% Guessing. After learning, $65 \%$ students who have a scientific conceptions (scientific knowledges) with average increase of $60 \%$ in the medium category. Lack of knowledge $26 \%$ students with average decerease of $67 \%$. In M1 misconception, 100\% of students misconceptions are medicated, M2 are $82 \%, M 3$ are $100 \%$ and $87 \%$ in M4. The results showed that the percentage of students whose misconceptions remediated above $80 \%$ are in the High category so it can be concluded that virtual simulation media application on ECIRR learning model can remediate student's misconceptions about Change of matter.
\end{abstract}

Keywords: virtual simulation, ECIRR, misconception, change of matter

\begin{abstract}
Abstrak: Penelitian ini bertujuan untuk memperoleh gambaran tentang pengaruh pengaplikasian media simulasi virtual pada model pembelajaran ECIRR (Elicit, Confront, Identify, Resolve, Reinforce) untuk meremediasi miskonsepsi siswa SMA pada materi Perubahan Wujud Zat. Media simulasi virtual digunakan untuk memvisualisasikan fenomena perubahan wujud zat yang bersifat mikroskopis dan tidak dapat dilihat dengan pengamatan langsung. Media simulasi virtual diaplikasikan pada model pembelajaran ECIRR pada tahapan Resolve untuk meremediasi miskonsepsi siswa. Penelitian ini dilakukan kepada 38 orang siswa kelas 2 SMA di salah satu SMA di Kabupaten Bandung Barat dengan metode campuran kualitatif-kuantitatif dan desain penelitian one-group pretest-posttest. Sampel penelitian ditentukan dengan purposive sampling, dengan kriteria yang dijadikan sebagai sampel adalah siswa yang mengalami miskonsepsi pada materi perubahan wujud zat. Miskonsepsi dan perubahan konsepsi siswa didiagnosa menggunakan tes diagnostik miskonsepsi three-tier test. Penelitian ini berfokus pada empat miskonsepsi yang ditemukan pada siswa yang diberi label M1, M2, M3 dan M4. Rata-rata kuantitas siswa yang mengalami miskonsepsi pada pretest tidak mencapai rata-rata $50 \%$ di setiap label, sementara sisanya tersebar dalam kategori lain, seperti $12 \%$ Scientific knowledge, 26\% Lack of knowledge, 9\% Error, dan 30\% Guessing. Setelah pembelajaran, siswa yang memiliki konsepsi ilmiah (Scientific knowledge) 65\%, mengalami rata-rata peningkatan $60 \%$ pada kategori sedang. Siswa yang kurang memahami konsep (Lack of knowledge) 26\%
\end{abstract}


mengalami rata-rata penurunan sebesar $67 \%$. Pada miskonsepsi M1, $100 \%$ miskonsepsi siswa teremediasi, M2 sebanyak $82 \%$, M3 sebanyak $100 \%$ dan pada M4 sebanyak $87 \%$. Hasil penelitian menunjukkan bahwa persentase kuantitas siswa yang miskonsepsinya teremediasi di atas $80 \%$ berada pada kategori Tinggi sehingga dapat disimpulkan bahwa aplikasi media simulasi virtual pada model pembelajaran ECIRR dapat meremediasi miskonsepsi siswa.

Kata kunci : media simulasi virtual, model pembelajaran ECIRR, miskonsepsi, perubahan wujud zat.

\section{PENDAHULUAN}

Salah satu fungsi dan tujuan pembelajaran Fisika adalah memahami, menerapkan, dan menjelaskan pengetahuan faktual, konseptual, prosedural, dan metakognitif dalam ilmu pengetahuan, teknologi, seni, budaya, dan humaniora dengan wawasan kemanusiaan, kebangsaan, kenegaraan, dan peradaban terkait penyebab fenomena dan kejadian, serta menerapkan pengetahuan prosedural pada bidang kajian yang spesifik sesuai dengan bakat dan minatnya untuk memecahkan masalah (Depdiknas, 2013). Pembelajaran Fisika menuntut siswa untuk memahami konsep Fisika agar dapat diterapkan dalam menyelesaikan masalah maupun dalam kehidupan sehari-hari. Rosser (dalam Dahar, 1996) mengatakan bahwa konsep merupakan suatu abstraksi yang mewakili satu kelas objek-objek, kejadian-kejadian, kegiatankegiatan, atau hubungan-hubungan, yang mempunyai atribut-atribut yang sama. Semua konsep yang dipahami oleh siswa berkembang dari pengalaman hidup sehari-hari dan berubah pada saat tertentu. Tidak ada dua orang yang memiliki pengalaman yang persis sama, maka konsepsi yang dibentuk orang mungkin berbeda. Masing-masing siswa memiliki konsepsi awal yang mereka dapatkan dari berbagai peristiwa yang dialaminya dan konsep itu mungkin tidak sesuai dengan konsep ilmiah. Kartal (2011) mengatakan, ketika siswa mendefinisikan konsepsi tertentu berbeda dengan konsep ilmiah, maka terjadilah miskonsepsi. Miskonsepsi akan membuat siswa mengambil kesimpulan yang berbeda walaupun diberi fenomena atau masalah yang sama. Miskonsepsi yang dialami siswa harus diremediasi karena akan mempengaruhi bagaimana pemahamannya terhadap konsep Fisika.

Perubahan wujud zat merupakan salah satu materi Fisika yang dekat dan banyak ditemukan dalam kehidupan sehari-hari siswa. Namun proses perubahan wujud zat yang bersifat mikroskopis mengakibatkan siswa banyak mengalami kesulitan dalam memahami konsep perubahan wujud zat sehingga banyak yang mengalami miskonsepsi. Hasil studi pendahuluan pada penelitian sebelumnya, banyak ditemukan siswa yang mengalami miskonsepsi pada materi perubahan wujud zat. Kartal et al (2011) menemukan dalam penelitiannya bahwa siswa mengalami miskonsepsi dalam materi perubahan wujud zat. Beberapa miskonsepsi siswa yang ditemukan anatara lain: (1) Penguapan hanya terjadi pada saat mendidih, (2) Ketika es berubah menjadi air, volumenya tidak berubah, dan (3) Air dapat menguap pada suhu berapapun. Chu, Hye-Eun et al (2012) juga menemukan bahwa banyak siswa yang mengalami miskonsepsi pada materi perubahan wujud zat. Miskonsepsi yang ditemukan antara lain : (1) Jika air dipanaskan, maka yang terjadi hanyalah perubahan suhu dan (2) Air hanya mendidih pada suhu $100^{\circ} \mathrm{C}$. Miskonsepsi yang dialami oleh siswa sudah terbentuk dari pengalaman sehari-hari dan melekat kuat dalam pikiran siswa sehingga sulit untuk diubah. Oleh karena itu, dibutuhkan suatu proses pembelajaran yang dapat mendeteksi pengetahuan dan keyakinan awal siswa serta mengoreksi jika tidak sesuai dengan konteks ilmiah (Srisawasdi dan Siriporn, 2014). Proses pembelajaran diharapkan dapat mengubah, memperbaiki dan merekonstruksi pemahaman konsep awal siswa sehingga konsep siswa sesuai dengan konsep ilmiah.

Proses pengubahan miskonsepsi siswa dengan konsep yang dapat diterima secara ilmiah dikenal dengan pengubahan konseptual (Suparno, 2013). Pengubahan konsepsi siswa dapat 
diawali dengan membuat siswa merasa tidak puas dengan konsepsinya yang telah ada. Ketidakpuasan itu akan menimbulkan konflik dalam pikiran siswa (konflik kognitif). Konflik kognitif menuntut adanya suatu pembuktian akan konsepsi yang benar secara ilmiah untuk meyakinkan siswa akan perubahan konsep yang dialaminya. Pada saat terjadi konflik kognitif pada siswa akan terjadi ketidakseimbangan antara konsepsi yang selama ini diketahui siswa dengan konsepsi yang disajikan oleh guru sehingga lebih mudah untuk menawarkan konsepsi baru yang sesuai dengan konsepsi ilmiah. Oleh karena itu, harus diciptakan situasi yang dapat menimbulkan konflik pada pikiran siswa. Strategi konflik kognitif dapat diterapkan pada model pembelajaran yang berorientasi pada model pengubahan konsepsi (conceptual change model). Wenning (2008) mengusulkan penerapan model ECIRR (Elicit-Confront-IdentifyResolve-Reinforce) untuk mengatasi miskonsepsi pada siswa. Kelima tahapan pada model ECIRR saling berkaitan dan saling mendukung keberhasilan proses pembelajaran. Pada tahap Elicit (dapatkan), guru menggali pengetahuan awal siswa. Tahap Confront (benturkan), guru menyangkal konsepsi awal siswa. Tahap Identify (Identifikasi), guru mengidentifikasi konsepsi alternatif yang dialami siswa. Pada tahap Resolve (pecahkan), guru membantu untuk meremediasi miskonsepsi siswa. Pada tahap akhir, Reinforce (kuatkan), guru mengecek pengubahan konsepsi pada siswa yang sebelumnya mengalami miskonsepsi. Dengan demikian, bisa dilihat apakah miskonsepsi siswa sudah teremediasi atau belum.

Strategi konflik kognitif membutuhkan suatu media untuk menyajikan fakta riil untuk meremediasi miskonsepsi siswa. Bawaneh, dkk (2010) dalam penelitiannya menggunakan media peta konflik (conflict maps) untuk meremediasi miskonsepsi siswa. Namun penggunaan media peta konflik (conflict maps) membutuhkan waktu yang lama dalam proses pembelajarannya karena siswa memerlukan waktu yang lama dalam pembuatan peta konflik. Guru yang akan menggunakan media peta konflik (conflict maps) juga harus mengikuti pelatihan pembuatan peta konflik (conflict maps) terlebih dahulu agar dapat membimbing siswa dalam pembuatan peta konflik. Liao, Y dan She, H(2009) menggunakan pembelajaran berbasis web (web-based learning) untuk mengubah konsepsi siswa. Namun penggunaan pembelajaran berbasis web membutuhkan jaringan internet yang kuat serta jumlah komputer yang cukup untuk masing-masing siswa sehingga sulit diterapkan di sekolah yang fasilitasnya kurang memadai.

Penelitian yang dilakukan oleh Suhandi et al (2008) menunjukkan bahwa media simulasi virtual dapat meningkatkan pemahaman konsep siswa dan meremediasi miskonsepsi. Penggunaan media simulasi virtual untuk pengubahan konsepsi siswa masih sangat jarang dilakukan (Olympiou, et al, 2013). Simulasi virtual dapat memvisualisasikan perilaku makroskopis dan mikroskopis suatu fenomena sehingga dapat membantu siswa mengamati fenomena yang tidak dapat diamati secara langsung, dan menghubungkannya dengan fenomena yang dapat diamati secara langsung (Srisawasdi dan Siriporn, 2014). Penggunaan simulasi virtual lebih efisien dari segi waktu maupun peralatan yang dibutuhkan. Penggunaan media simulasi virtual dapat mensimulasikan perubahan susunan partikel pada proses perubahan wujud zat secara mikroskopis dan bagaimana akibat perubahan susunan partikel penyusun zat terhadap perubahan wujud zat secara makroskopis. Media simulasi virtual dapat digunakan tanpa harus terhubung dengan internet dan membutuhkan peralatan yang lebih sedikit sehingga penggunaanya lebih efisien baik dari segi waktu maupun biaya. Dengan menggunakan simulasi virtual, siswa dapat menggali dan mengkonstruksi konsepnya melalui pengamatan yang sesuai dengan konsep ilmiah sehingga terhindar dari miskonsepsi. Sanny dan Suhandi (2016) dalam penelitiannya mengembangkan media simulasi virtual yang berorientasi untuk meremediasi miskonsepsi siswa pada materi Perubahan Wujud Zat namun belum meneliti bagaimana pengaruhnya jika diaplikasikan dalam pembelajaran. Berdasarkan 
hal tersebut, maka peneliti menganggap perlu melakukan penelitian lanjutan tentang "Aplikasi Media Simulasi Virtual pada Model Pembelajaran ECIRR untuk Meremediasi Miskonsepsi Siswa pada Materi Perubahan Wujud Zat

\section{METODE PENELITIAN}

Penelitian ini dilakukan kepada 38 orang siswa kelas 2 SMA di salah satu SMA di Kabupaten Bandung Barat dengan metode campuran kualitatif-kuantitatif dan desain penelitian one-group pretest-posttest. Sampel penelitian ditentukan dengan purposive sampling, dengan kriteria yang dijadikan sebagai sampel adalah siswa yang mengalami miskonsepsi pada materi perubahan wujud zat. Skema penelitian menggunakan desain concurrent embedded yaitu metode penelitian yang menggabungkan antara metode penelitian kualitatif dan kuantitatif dengan mencampurkan kedua metode tersebut secara tidak berimbang, dalam satu kegiatan penelitian mungkin 70\% menggunakan metode kuantitatif dan 30\% menggunakan metode kualitatif atau sebaliknya (Sugiyono, 2014). Dalam penelitian ini, bobot metode penelitian kuantitatif lebih besar dari pada kualitatif. Berikut skema penelitian digambarkan seperti pada gambar 1 .

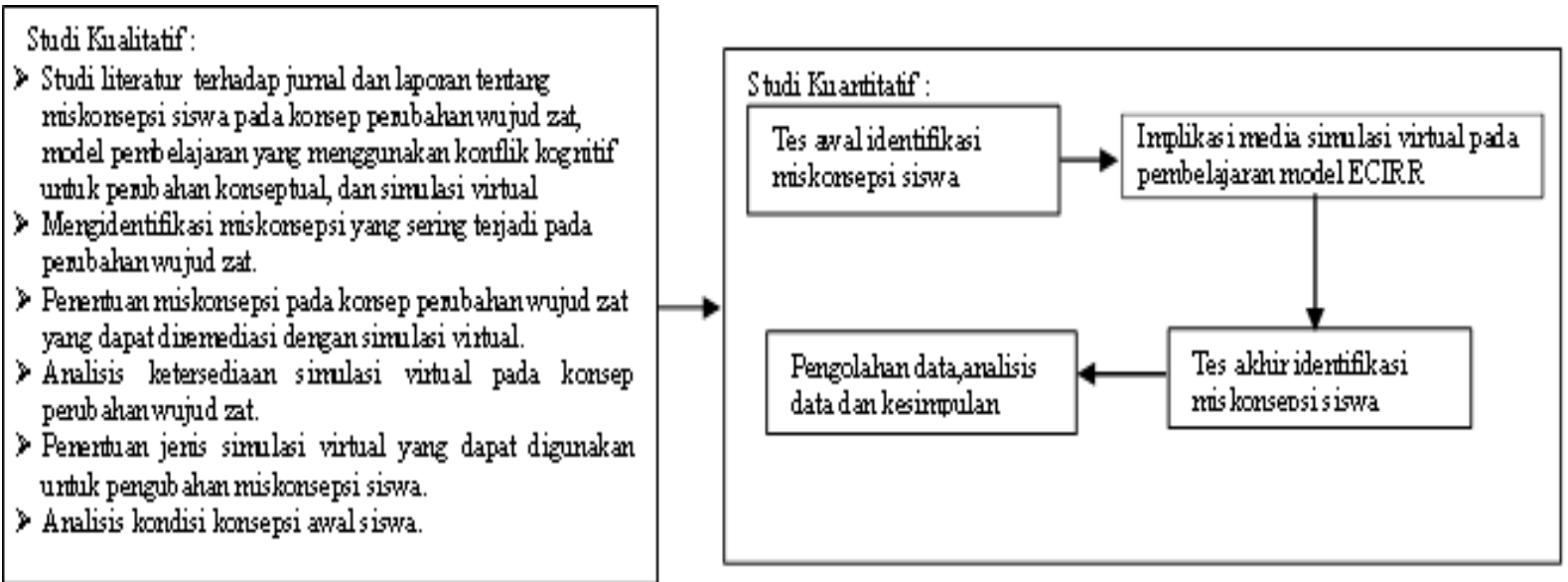

\section{Gambar 1. Skema Penelitian}

Miskonsepsi dan perubahan konsepsi siswa didiagnosa menggunakan tes diagnostik miskonsepsi three-tier test yang sudah divalidasi oleh tiga orang ahli. Soal three-tier test ini berupa soal pilihan ganda dengan 3 tier (tingkat) pertanyaan dimana tier pertama menanyakan materi, tier kedua menanyakan alasan dari jawaban tier pertama, dan tier ketiga berupa indeks keyakinan dalam menjawab. Permasalahan dalam kombinasi jawaban siswa muncul karena bentuk soal yang disusun dalam penelitian memungkinkan adanya siswa yang memilih jawaban yang tidak berhubungan. Jawaban yang tidak berhubungan ini dapat mengindikasikan adanya kecerobohan, adanya unsur menebak, atau kurangnya minat, perhatian siswa, atau pemahaman siswa mengenai cara mengerjakan soal. Kaltakci dan Didis (2007) mempertimbangkan jawaban seperti ini sebagai jawaban error (salah). Untuk membedakan siswa yang paham konsep, mengalami miskonsepsi, tidak tahu konsep dan menebak, digunakan teknik analisis jawaban yang merujuk pada kriteria yang ditulis oleh Kaltacki dan Didis (2007), seperti dalam Tabel 1: 
Tabel 1. Panduan untuk menentukan keadaan konsepsi siswa berdasarkan data hasil Three Tier Test

\begin{tabular}{|c|c|c|c|}
\hline Jawaban & Alasan & $\begin{array}{l}\text { Tingkat } \\
\text { Keyakinan }\end{array}$ & Kriteria \\
\hline Benar & Benar & Yakin & $\begin{array}{l}\text { Scientific Knowledge (Pengetahuan } \\
\text { Ilmiah) }\end{array}$ \\
\hline Salah & Benar & Yakin & Eror \\
\hline Benar & Salah & Yakin & \multirow[t]{2}{*}{ Misconception (Miskonsepsi) } \\
\hline Salah & Salah & Yakin & \\
\hline Benar & Benar & Tidak Yakin & \multirow{4}{*}{$\begin{array}{l}\text { (Lack of knowledge) Tidak } \\
\text { Tahu } \\
\text { Konsep }\end{array}$} \\
\hline Salah & Benar & Tidak Yakin & \\
\hline Benar & Salah & Tidak Yakin & \\
\hline Salah & Salah & Tidak Yakin & \\
\hline
\end{tabular}

Dalam penelitian ini, untuk menentukan apakah jawaban siswa termasuk dalam miskonsepsi yang dimaksud, maka peneliti menyusun seperangkat alternatif pilihan jawaban yang menunjukkan tiap label miskonsepsi yang ingin diidentifikasi. Hal ini mengingat bahwa tidak semua pola jawaban Benar-Salah-Yakin (B-S-Y) dan Salah-Salah-Yakin (S-S-Y) sesuai dengan label miskonsepsi yang ingin diidentifikasi. Oleh karena itu, pola jawaban siswa yang B-S-Y dikategorikan sebagai menebak dan S-S-Y diluar dari alternatif pilihan yang menunjukkan miskonsepsi yang diinginkan dimasukkan ke dalam 2 kategori. Pertama, menebak, yaitu jika menjawab S-S-Y namun pilihan tier I dan tier II tidak berkaitan satu sama lain. Kedua, diketahui sebagai miskonsepsi baru jika pilihan tier I dan II saling berkaitan namun konsepnya salah. Soal diuji kelayakan dengan menggunakan tes realibilitas dengan realiabilitas instrumen soal adalah sebesar $r_{x y}=0,56$ termasuk dalam kategori cukup.

Efektifitas penggunaan media simulasi virtual dalam pembelajaran fisika yang berorientasi pengubahan konsepsi siswa pada materi perubahan wujud zat, ditentukan berdasarkan persentase kuantitas siswa yang konsepsinya berubah dari miskonsepsi menjadi konsepsi yang ilmiah, dengan menggunakan kriteria seperti pada Tabel 2, yang diadaptasi dari Suhandi dan Wibowo (2012).

Tabel 2. Kriteria Efektifitas Penggunaan Media dalam Pembelajaran Fisika

\begin{tabular}{cc}
\hline $\begin{array}{c}\text { Persentase Siswa yang } \\
\text { Miskonsepsinya Terremediasi } \\
(\%)\end{array}$ & Kriteria Efektifitas \\
\hline$>75 \%$ & Tinggi \\
$50 \%-75 \%$ & Sedang \\
$<50 \%$ & Rendah \\
\hline
\end{tabular}

\section{HASIL DAN PEMBAHASAN}

\section{Media Simulasi Virtual}

Hasil studi literatur menunjukkan bahwa banyak siswa yang mengalami miskonsepsi perubahan wujud zat yang ditemukan oleh peneliti terdahulu. Yeo dan Marjan (2001), Kartal et al (2011), Chu, H et al (2012), Mahmudah (2013), dan Siregar, P (2014) menemukan dalam penelitiannya bahwa siswa mengalami miskonsepsi pada materi perubahan wujud zat. Hal ini memperlihatkan bahwa miskonsepsi tentang perubahan wujud zat banyak terjadi pada 
siswa. Berdasarkan penemuan-penemuan sebelumnya, maka peneliti menetapkan miskonsepsi yang akan diidentifikasi dan diremediasi dalam penelitian ini adalah sebagai berikut: (1) proses penguapan harus didahului oleh proses mendidih (label M1); (2) butiran air pada pengembunan berasal dari peristiwa kapilaritas atau udara yang mengembun (label M2); (3) air mendidih hanya pada suhu $100^{\circ} \mathrm{C}$ (label M3) dan (4) massa jenis es /zat padat lebih besar dari massa jenis air/zat cair (Label M4). Miskonsepsi yang dialami siswa diremediasi menggunakan media simulasi virtual yang dikembangkan oleh Sanny dan Suhandi (2016) dengan menggunakan aplikasi macromedia flash 8.0. yang diaplikasikan dalam model pembelajaran ECIRR pada tahap Resolve.

Pada tahap Elicit (dapatkan), guru menggali pengetahuan awal siswa tentang perubahahan wujud zat dengan menyajikan contoh fenomena perubahan wujud zat. Tahap Confront (benturkan), guru menyangkal konsepsi awal siswa dengan mengajukan fenomena yang konsepnya mirip namun konsepsi siswa berbeda sehingga menimbulkan konflik kognitif bagi siswa. Tahap Identify (Identifikasi), guru mengidentifikasi konsepsi alternatif yang dialami siswa. Pada tahap Resolve (pecahkan), guru membantu untuk meremediasi miskonsepsi siswa. Guru memvisualisasikan proses perubahan wujud zat secara makroskopik dan mikroskopik dengan menggunakan media simulasi virtual. Dengan memvisualisasikan bagaimana proses perubahan wujud zat secara makroskopik dan mikroskopik, guru memberikan kesempatan bagi siswa untuk memecahkan sendiri ketidaksesuaian konsep yang mereka miliki dengan membandingkan konsep yang divisualisasikan melalui media simulasi vitual. Pengubahan konsepsi siswa lebih mudah karena siswa disajikan secara langsung proses perubahan wujud zat, bagaimana suhu mempengaruhi susunan partikel penyusun zat dan pengaruh perubahan susunan partikel zat terhadap perubahan wujud benda. Pada tahap akhir, Reinforce (kuatkan), guru mengecek pengubahan konsepsi pada siswa yang sebelumnya mengalami miskonsepsi. Dengan demikian, bisa dilihat apakah miskonsepsi siswa sudah teremediasi atau belum.

Karakteristik media yang dapat digunakan untuk meremediasi miskonsepsi siswa pada materi perubahan wujud zat dapat disimpulkan, antara lain: (1) Media menampilkan proses perubahan wujud zat secara makroskopis sekaligus mikroskopis; (2) Mencakup simulasi fenomena mencair, membeku, menguap, mengembun, menyublim dan mengkristal; (3) Dilengkapi dengan tombol navigasi sehingga mudah digunakan (user friendly) dan (4) Tampilan menarik dan informatif; (5) Tampilan dengan simulasi visual tanpa audio/suara. (Sanny dan Suhandi, 2016). Tampilan media simulasi virtual yang akan digunakan dalam penelitian dapat dilihat pada Gambar 2.
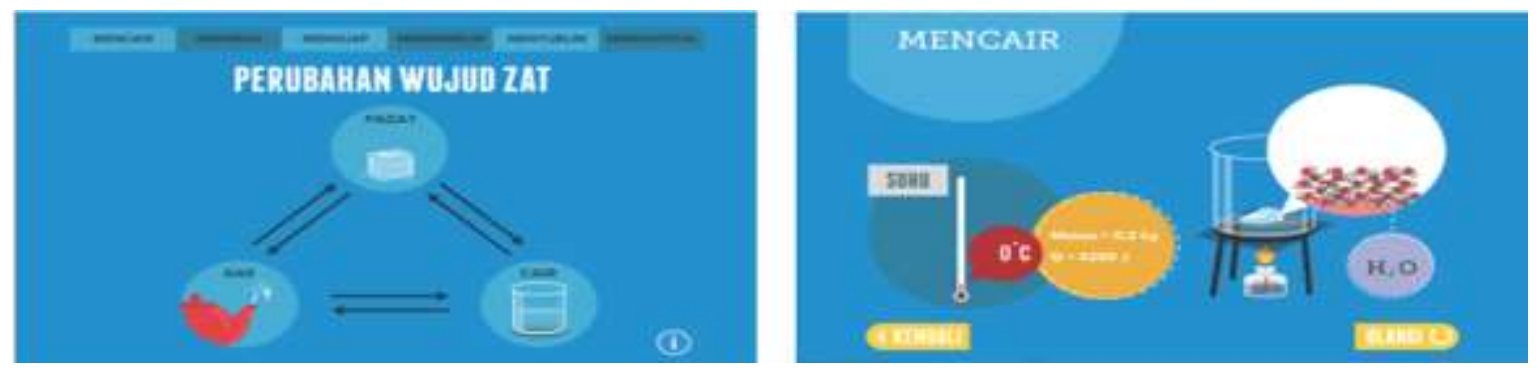

Gambar 2. Tampilan Media Simulasi Virtual Perubahan Wujud Zat

\section{Keadaan Konsepsi Siswa}

Data kuantitas siswa yang miskonsepsi diperoleh dari hasil pretest dan postest yang diukur menggunakan instrumen tes diagnostik miskonsepsi perubahan wujud zat berbentuk three tier test, selanjutnya disebut TDM dengan jumlah soal 12 butir. Rata-rata kuantitas siswa yang mengalami miskonsepsi (MS) pada pretest tidak mencapai 50\% di setiap label miskonsepsi, 
sementara sisanya tersebar dalam kategori lain, seperti 12\% Scientific knowledge (SK), 26\% Lack of knowledge (LK), 9\% Error(ER), dan 30\% Guessing(GS). Hal ini menunjukkan bahwa banyak siswa yang menebak jawaban dan kurang paham konsep pada mulanya. Setelah pembelajaran, siswa yang memiliki konsepsi ilmiah (Scientific knowledge) 65\%, mengalami rata-rata peningkatan $60 \%$ pada kategori sedang. Siswa yang kurang memahami konsep (Lack of knowledge) 26\% mengalami rata-rata penurunan sebesar $67 \%$. Rekapitulasi persentase siswa tiap kategori disajikan secara lengkap pada Tabel 3 berikut ini:

Tabel 3. Persentase kuantitas siswa tiap kategori untuk tiap item soal TDM

\begin{tabular}{|c|c|c|c|c|c|c|c|c|c|c|c|}
\hline \multirow[t]{3}{*}{$\begin{array}{c}\text { Label } \\
\text { Miskonsepsi }\end{array}$} & \multirow{3}{*}{$\begin{array}{l}\text { Item } \\
\text { Soal }\end{array}$} & \multicolumn{10}{|c|}{$\begin{array}{c}\text { Kuantitas siswa tiap kategori berdasarkan item soal 3TT } \\
(\%)\end{array}$} \\
\hline & & \multicolumn{2}{|c|}{ SK } & \multicolumn{2}{|c|}{ LK } & \multicolumn{2}{|c|}{ ER } & \multicolumn{2}{|c|}{ MS } & \multicolumn{2}{|c|}{ GS } \\
\hline & & pre & post & pre & post & pre & post & pre & post & pre & post \\
\hline \multirow[t]{3}{*}{ M1 } & Q1 & 24 & 87 & 18 & 3 & 0 & 0 & 21 & 0 & 37 & 11 \\
\hline & Q2 & 0 & 95 & 0 & 0 & 0 & 3 & 0 & 0 & 100 & 3 \\
\hline & Q3 & 11 & 61 & 29 & 13 & 8 & 11 & 32 & 0 & 21 & 16 \\
\hline \multirow[t]{3}{*}{ M2 } & Q4 & 11 & 58 & 21 & 5 & 26 & 16 & 5 & 0 & 37 & 21 \\
\hline & Q5 & 18 & 39 & 26 & 13 & 26 & 13 & 13 & 0 & 34 & 16 \\
\hline & Q6 & 8 & 29 & 42 & 21 & 24 & 16 & 11 & 5 & 29 & 15 \\
\hline \multirow[t]{3}{*}{ M3 } & Q7 & 8 & 89 & 37 & 0 & 5 & 5 & 37 & 0 & 13 & 5 \\
\hline & Q8 & 8 & 53 & 34 & 3 & 5 & 3 & 26 & 0 & 42 & 26 \\
\hline & Q9 & 0 & 55 & 42 & 8 & 21 & 16 & 18 & 0 & 21 & 18 \\
\hline \multirow[t]{3}{*}{ M4 } & Q10 & 11 & 53 & 24 & 16 & 21 & 8 & 32 & 0 & 24 & 13 \\
\hline & Q11 & 39 & 84 & 29 & 5 & 3 & 0 & 11 & 3 & 18 & 8 \\
\hline & Q12 & 8 & 79 & 5 & 0 & 5 & 3 & 76 & 13 & 5 & 5 \\
\hline
\end{tabular}

Berdasarkan Tabel 3, dapat dilihat bahwa terdapat perbedaan persentase di tiap kategori sebelum dan sesudah pembelajaran. Pada TDM item Q2 dan Q9, peresentase kuantitas siswa yang termasuk kategori Scientific Knowledge pada pretest sebanyak 0\%, artinya belum ada siswa yang memiliki konsepsi ilmiah pada kedua item tersebut. Namun setelah pembelajaran, persentase kuantitas siswa yang termasuk kategori Scientific Knowledge pada kedua item tersebut sebesar 95\% dan 55\%. Hal ini menunjukkan bahwa siswa mengalami pengubahan konsepsi pada kedua item itu. Setelah pembelajaran, persentase siswa yang termasuk kategori miskonsepsi terdapat pada item Q6 sebanyak 6\%, item Q11 3\% dan item Q12 sebesar 13\%. Hal ini menunjukkan bahwa siswa masih mengalami miskonsepsi pada beberapa item soal setelah pembelajaran namun dalam jumlah yang sangat sedikit.

\section{Efektifitas Penggunaan Media dalam Pembelajaran Fisika}

Efektifitas media simulasi virtual dalam pembelajaran fisika yang berorientasi pengubahan konsepsi siswa pada materi perubahan wujud zat, ditentukan berdasarkan persentase kuantitas siswa yang miskonsepsinya teremediasi. Data persentase kuantitas siswa yang miskonsepsinya teremediasi disajikan pada Tabel 4. 
Tabel 4. Persentase kuantitas siswa yang miskonsepsinya teremediasi

\begin{tabular}{ccccc}
\hline $\begin{array}{c}\text { Label } \\
\text { Miskonsepsi }\end{array}$ & $\begin{array}{c}\text { Pretest } \\
(\boldsymbol{\%})\end{array}$ & $\begin{array}{c}\text { Posttest } \\
(\boldsymbol{\%})\end{array}$ & $\begin{array}{c}\text { Persentase kuantitas } \\
\text { siswa yang } \\
\text { miskonsepsinya }\end{array}$ & Kategori \\
teremediasi (\%) & \\
\hline M1 & 19 & 0 & 100 & Tinggi \\
M2 & 10 & 2 & 82 & Tinggi \\
M3 & 27 & 0 & 100 & Tinggi \\
M4 & 39 & 5 & 87 & Tinggi \\
\hline
\end{tabular}

Pada label M1 dan M3, persentase siswa yang mengalami miskonsepsi pada posttest sebanyak $0 \%$ artinya semua miskonsepsi pada kedua label tersebut teremediasi. Pada label M2 persentase kuantitas siswa yang mengalami miskonsepsi sebanyak $2 \%$, hal ini menunjukkan masih ada siswa yang mengalami miskonsepsi yaitu sebanyak 2 orang. Namun jika dilihat dari jumlah siswa yang masih mengalami miskonsepsi setelah pembelajaran, jumlah terbanyak berada pada label M4 yaitu sebanyak 6 orang. Dari seluruh item soal TDM perubahan wujud zat, sebelum pembelajaran jumlah siswa yang mengalami miskonsepsi paling tinggi terdapat pada item kode soal Q12 sebanyak 29 orang dan paling rendah pada item soal Q2 dan Q4 sebanyak 5 orang. Namun setelah pembelajaran, pada item soal Q2 dan Q4 tidak ada lagi siswa yang mengalami miskonsepsi. Pada item soal Q12 masih terdapat 5 orang siswa yang mengalami miskonsepsi. Miskonsepsi yang diidentifikasi pada label M1 adalah "Penguapan hanya terjadi setelah proses mendidih". Pada TDM perubahan wujud zat, label M1 terdiri dari 3 item soal yaitu Q1, Q2 dan Q3. Kuantitas siswa yang mengalami miskonsepsi tertinggi terdapat pada item Q3 yaitu sebanyak $21 \%$, sedangkan terendah pada item Q2 hanya 5\% dan item Q1 sebanyak 21\%. Setelah pembelajaran, semua miskonsepsi yang dialami siswa sudah teremediasi. Hal yang menarik pada label M1 adalah ditemukannya miskonsepsi baru selain miskonsepsi yang ingin diidentifikasi yaitu "Penguapan terjadi hanya pada saat mendidih". Hal ini dapat dilihat dari pola jawaban siswa S-S-Y namun jawaban dan alasan berkaitan. TDM dirancang sedemikian rupa sehingga dapat menyaring miskonsepsi selain miskonsepsi yang ingin diidentifikasi. Hasil pretest menunjukkan tiga orang siswa dengan label S-01, S-18 dan S-23 memilih jawaban C-B-A yang menunjukkan jawaban ketiga siswa tersebut berpola S-S-Y namun saling berhubungan sehingga tidak bisa dimasukkan ke dalam kategori Guessing (menebak) dan dapat dianggap sebagai miskonsepsi yang baru di dalam penelitian ini. Miskonsepsi ini sama dengan miskonsepsi yang ditemukan oleh Yalvac, et al (2011) yang melakukan penelitian kepada 60 orang mahasiswa Fakultas Pendidikan Sains di Universitas Ahi Evran, Turki. Namun, setelah pembelajaran ketiga siswa tersebut tidak lagi mengalami miskonsepsi. Hal ini menunjukkan bahwa walaupun ketiga siswa tersebut mengalami miskonsepsi yang berbeda, namun tetap dapat diremediasi.

Miskonsepsi yang diidentifikasi pada label M2 adalah "Titik-titik air pada pengembunan berasal dari peristiwa kapilaritas atau dari udara yang mengembun". Pada TDM perubahan wujud zat, label M2 terdiri dari 3 item soal yaitu Q4, Q5 dan Q6. Kuantitas siswa yang mengalami miskonsepsi tertinggi terdapat ada item Q6 sebanyak 13\%, sedangkan paling rendah terdapat pada item Q5 hanya 5\% dan item Q7 sebesar 11\%. Setelah pembelajaran, terdapat 2 orang siswa yang masih mengalami miskonsepsi pada Q6. Hal yang menarik dari label M2 adalah label M2 merupakan label miskonsepsi dengan persentase kuantitas siswa yang miskonsepsinya terendah diantara semua label miskonsepsi yaitu hanya $10 \%$ pada pretest namun masih ada kuantitas siswa yang mengalami miskonsepsi pada postest sebesar 2\%. Pada Tabel 3 menunjukkan bahwa sebelum pembelajaran, pada item Q4 siswa yang 
kurang memahami konsep (Lack of Knowledge) sebanyak $21 \%$, Error 26\% dan Menebak (Guessing) sebanyak 37\%. Pada Q5 siswa yang kurang memahami konsep (Lack of Knowledge) sebanyak $26 \%$, Error 26\% dan Menebak (Guessing) sebanyak 34\%. Pada Q6 siswa yang kurang memahami konsep (Lack of Knowledge) sebanyak $42 \%$, Error 24\% dan Menebak (Guessing) sebanyak 29\%. Kuantitas siswa yang termasuk kategori paham konsep (Scientific Knowledge) 11\% pada Q4, 18\% pada Q5 dan hanya 8\% pada Q6. Hal ini menunjukkan, rendahnya kuantitas siswa yang miskonsepsi bukan karena kuantitas siswa yang masuk kategori memahami konsep tinggi tetapi karena kuantitas siswa yang kurang memahami konsep, error dan menebak yang berada pada persentase yang tinggi. Setelah pembelajaran, masih ada 2 orang siswa yang mengalami miskonsepsi pada item Q6, siswa yang kurang memahami konsep (Lack of Knowledge) sebanyak $21 \%$, Error 16\% dan Menebak (Guessing) sebanyak 15\%. Hasil tes ini menunjukkan bahwa masih ada siswa yang sulit memahami konsep pengembunan, walaupun persentase jumlah siswa yang miskonsepsinya teremediasi pada label M2 termasuk dalam kategori Tinggi. Kemungkinan penyebab adanya siswa yang masih miskonsepsi pada konsep pengembunan disebabkan oleh proses pengembunan pada media yang masih berupa pendinginan menggunakan es, berbeda dengan fenomena pengembunan yang sebenarnya. Sehingga masih ada siswa yang miskonsepsinya belum teremediasi.

Miskonsepsi yang diidentifikasi pada label M3 adalah "Air hanya mendidih pada suhu $100^{\circ} \mathrm{C}$ ". Pada TDM perubahan wujud zat, label M3 terdiri dari tiga item soal yaitu Q7, Q8 dan Q9. Kuantitas siswa yang mengalami miskonsepsi tertinggi sebelum pembelajaran terdapat pada item Q7 yaitu sebanyak $37 \%$, sedangkan terendah pada item Q9 hanya 18\% dan item Q8 sebanyak 26\%. Setelah pembelajaran, persentase kuantitas siswa yang miskonsepsinya teremediasi sebesar $100 \%$. Hal ini menunjukkan bahwa semua miskonsepsi yang dialami siswa sudah teremediasi. Sebelum pembelajaran, pada item Q9 tidak ada siswa yang paham akan konsep yang ditanyakan. Soal item Q9 pada TDM perubahan wujud zat merupakan soal aplikasi konsep pengaruh tekanan terhadap titik didih. Sebelum pembelajaran, tidak ada siswa yang menjawab dengan benar soal item Q9, namun pada Q7 dan Q8 terdapat 8\% siswa yang dapat menjawab dengan benar, padahal ketiga item soal ini mengaplikasikan konsep yang sama. Hal ini menunjukkan tidak ada siswa yang benar-benar memahami konsep pengaruh tekanan terhadap titik didih air. Simulasi virtual yang dikembangkan dalam penelitian ini, belum mencakup pengaruh tekanan terhadap titik didih air. Untuk mengatasi kekurangan tersebut, pada saat proses pembelajaran, siswa disajikan video praktikum langsung untuk melihat titik didih air pada ketinggian yang berbeda di jalur pendakian gunung Everest. Pada ketinggian 1300 mdpl di daerah Khatmandu, air mendidih pada suhu $97^{\circ} \mathrm{C}$. Naik pada ketinggian $3500 \mathrm{mdpl}$ di daerah Namche Bazar, air mendidih pada suhu $91^{\circ} \mathrm{C}$. Pada ketinggian $5300 \mathrm{mdpl}$ di daerah perkemahan gunung Everest, air sudah mendidih pada suhu $82^{\circ} \mathrm{C}$. Video eksperimen langsung membuktikan bahwa semakin tinggi suatu tempat maka titik didih air di tempat itu akan turun karena tekanannya semakin rendah. Namun pada saat pembelajaran, ketika ditanyakan soal item Q9 kepada siswa, tidak ada yang yakin bahwa air dapat mendidih pada suhu ruangan. Peneliti menanyakan alasan siswa, 75\% siswa mengatakan bahwa walaupun air dapat mendidih di bawah $100^{\circ} \mathrm{C}$, tetapi tidak mungkin air dapat mendidih pada suhu ruangan yang hanya $25^{\circ} \mathrm{C}$. Siswa mengatakan, titik didih air akan berada diantara $80^{\circ} \mathrm{C}-120^{\circ} \mathrm{C}$. Hal ini juga digambarkan pada hasil postest siswa, hanya $58 \%$ yang menjawab dengan benar walaupun pembelajaran sudah dibantu dengan video eksperimen langsung. Berdasarkan pada hasil analisis pada item Q9, media simulasi virtual perubahan wujud zat yang digunakan dalam penelitian ini, perlu dikembangkan lagi dengan menambah pengaruh tekanan terhadap titik didih air. 
Miskonsepsi yang diidentifikasi pada label M4 adalah "Massa jenis es (padat) lebih besar dari massa jenis air (cair)". Pada TDM perubahan wujud zat, label M4 terdiri dari tiga item soal yaitu Q10, Q11 dan Q12. Sebelum pembelajaran, kuantitas siswa yang mengalami miskonsepsi tertinggi terdapat pada item Q12 yaitu sebanyak 76\%, sedangkan terendah terdapat pada Q11 hanya 11\% dan Q10 sebanyak 62\%. Setelah pembelajaran, item Q10 sudah teremediasi secara keseluruhan dengan persentase kuantitas siswa yang miskonsepsinya teremediasi sebesar 100\%, sedangkan $3 \%$ siswa pada item Q11 masih mengalami miskonsepsi. Persentase kuantitas siswa yang masih miskonsepsi pada item Q12 mencapai $13 \%$, dan merupakan persentase tertinggi diantara semua item soal. Label M4 merupakan label dengan kuantitas siswa dengan miskonsepsi tertinggi pada pretest yaitu sebesar 39\%. Hasil identifikasi konsepsi siswa yang dilakukan peneliti pada tahap Identification menujukkan bahwa 100\% siswa berpendapat bahwa massa jenis es lebih besar dari massa jenis air. Pendapat siswa ini disertai dengan alasan bahwa massa jenis zat padat selalu lebih besar dari zat cair. Walaupun setelah proses pembelajaran masih ada $5 \%$ siswa yang masih miskonsepsi, kuantitas siswa yang miskonsepsinya teremediasi pada label M4 berada pada angka $87 \%$ termasuk kategori Tinggi. Hal ini menunjukkan bahwa miskonsepsi siswa dapat diremediasi. Kemungkinan penyebab masih ada siswa yang miskonsepsi pada label M4 item Q12 karena fenomena yang disajikan pada soal jauh berbeda dengan contoh yang diberikan ketika pembelajaran dan memerlukan analisis tentang perubahan volume es ketika berubah menjadi air.

\section{KESIMPULAN}

Berdasarkan hasil penelitian dan analisis data, persentase kuantitas siswa yang miskonsepsinya teremediasi di atas $80 \%$ berada pada kategori Tinggi. Sehingga dapat disimpulkan bahwa: (1) aplikasi media simulasi virtual pada model pembelajaran ECIRR dapat meremediasi miskonsepsi yang dialami siswa dan juga dapat menyaring miskonsepsi yang baru; (2) media simulasi virtual efektif digunakan untuk meremediasi miskonsepsi siswa pada materi Perubahan Wujud Zat.

\section{UCAPAN TERIMAKASIH}

Penulis mengucapkan terimakasih kepada LPPM Universitas Pelita Harapan yang sudah membantu dalam mendanai publikasi ilmiah saya ini.

\section{DAFTAR PUSTAKA}

Alwan, A. (2010) Misconception of Heat and Temperature Among Physics Students. ScienceDirect. Procedia Social and Behavioral Scinences. 12 (11); 600-614

Anderson, Lorin W \& David R K.(2001) Kerangka Landasan untuk Pembelajaran, Pengajaran dan Asessment (Terjemahan). Pustaka Pelajar, Yogyakarta.

Arifiadi, N., Tomo, dan Haratua. (2013). Penggunaan Metode Demonstrasi Berbantuan Flip Chart untuk Meremedisi Miskonsepsi Siswa Tentang Getaran di SMP. Skripsi Pendidikan Fisika FKIP Universitas Tanjungpura. Pontianak.

Bawaneh, A.K.A, dkk. (2010). The Effectiveness of Conflict Maps and V-Shape Teaching Method in Science Conceptual Change among Eight-Grade Students in Jordan. Journal of International Education Studies. Yordania. 3 (1); 96-108

Creswell, J.W. (2014). Research DesignPendekatanKualitatif, Kuantitatif, dan 
Mixed.Yogyakarta :PustakaPelajar.

Chu, H et.al (2012). Evaluation of Student's Understanding of Thermal Concepts in Everyday Contexts. International Journal of Science Education. 34 (10); 1509-1534

Dahar, R.W. (2011).Teori-Teori Belajar dan Pembelajaran. Penerbit Erlangga.Jakarta.

Depdiknas. (2013). Kurikulum 2013 : Kompetensi Dasar Sekolah Menengah (SMA) / Madrasah Aliyah (MA). Jakarta: Depdiknas.

Fitriana, I.S. (2010). Penggunaan Multi Media Interaktif Dalam Proses Pembelajaran Materi Teori Kinetic Gas Untuk Meningkatkan Pemahaman Konsep Dan Keterampilan Berpikir Kreatif Siswa SMA. Thesis Sekolah Pascasarjana Universitas Pendidikan Indonesia. Bandung

Hamdani. (2013). Penerapan Model ECIRR Menggunakan Kombinasi Real Laboratory dan Virtual Laboratory untuk Mereduksi Miskonsepsi dan Meningkatkan Keterampilan Proses Sains Mahasiswa Tentang Konsep-Konsep Rangkaian Listrik. Thesis Sekolah Pascasarjana Universitas Pendidikan Indonesia. Bandung.

Hikmat, dkk. (2014). Strategi Konflik Kognitif Berbantuan Media Simulasi Virtual dalam Pembelajaran Fisika Berorientasi Pengubahan Konseptual untuk Meningkatakan Pemahaman Konsep dan Menurunkan Kuantitas Siswa yang Miskonsepsi. Prosiding Pertemuan Ilmiah XXVIII HFI Jateng \& DIY, Yogyakarta. 342- 347.

Kartal, T., Ozturk, N., dan Yalvac, H.G. (2011).Misconceptions of Sciences Teacher Candidats about Heat and Temperature. ScienceDirect. Procedia Social and Behavioral Scinences. 15; 2758-2763

Kusuma, N.M.Y., Warta, I.W., dan Abadi, I.B.G. (2014). Pengaruh Model Pembelajaran Elicit Confront Identify Resolve Reinforce (ECIRR) Berbantuan Media Audio Visual Terhadap Hasil Belajar Matematika Siswa Kelas VI SD Gugus Sanskerta T.A. 2013/2014. E-Journal Mimbar PGSD Universitas Pendidikan Ganesha. 2 (1); 1-11

Kaltacki, D dan Didis, N.(2007). Indentification of Pre-Service Physics Teachers"s Misconceptions on Gravity Concept: A Study with a 3-Tier Miscopception Test. Sixth International Conference of The Balkan Physical Union. American Institute of Physics. 899; 499-500.

Liao, Y dan Chen, Y. (2007). The Effect of Computer Simulation on Student Learning : A Meta-Analysis of Studies in Taiwan. Journal of Information Technology and Aplications. Taiwan. 2 (2); 69-79

Liao, Y dan She, H. (2009). Enchancing Eight Grade Student's Scientific Conceptual Change and Scientific Reasoning through a Web-based Learning Program. Journal of Educational Technology \& Society. Taiwan.12 (4); 228-240

Mardana. (2004). Pengembangan Model Simulasi Komputer Berorientasi Konstruktivisme Sebagai Inovasi Teknologi Pembelajaran Pengubah Miskonsepsi untuk Meningkatkan Hasil Belajar Fisika Siswa SMU. Jurnal Pendidikan dan Pengajaran IKIP Negeri Singaraja, No. 4 TH. XXXVII Oktober 2004; 50-71

Olympiou, G., Zacharias, Z., dan deJong, T. (2013). Making the Invisiable Visible: Enhancing Student's Conceptual Understanding by Introducing Representations of Abstact Objects in a Simulation. Jurnal Sains Internsional. Springer. 41 ; 575-596 
Sanny, S. S dan Suhandi (2016). Pengembangan Media Simulasi Virtual untuk Pembelajaran Fisika yang Berorientasi pada Pengubahan Konsepsi Siswa pada Materi Perubahan Wujud Zat. Prosiding Sinafi 2016 Pendidikan Fisika UPI. Bandung.153-158

Sanoto, H. (2012). Pengaruh Penggunaan Media Pembelajaran Macromedia Flash 8.0 Terhadap Hasil Belajar IPA Siswa Kelas V SDN 01 Kebumen Semarang T.A.2011/2012. Skripsi Universitas Kristen Satya Giagana. Semarang.

Sitinjak, D. (2014). Pengembangan Program Simulasi Materi Kelarutan dan Hasil Kali Kelarutan untuk Membangun Pemahaman Konsep dan KPS Siswa. Thesis Sekolah Pascasarjana Universitas Pendidikan Indonesia. Bandung.

Srisawasdi, N \& Siriporn K. (2014) Supporting Student's Conceptual Development of Light Refraction by Simulation-based Open Inquiry with Dual-situated Learning Model. Jurnal Computer Education. Springer. 1 (1); 49-79

Sugiyono. (2009). Metode Penelitian Kuantitatif Kualitatif dan $R \& D$. Bandung. Alfabeta.

Sugiyono, (2013).Metode Penelitian Kombinasi (Mixed Methods). Bandung. Alfabeta

Suhandi, A, dkk.(2008). Efektifitas Penggunaan Media Simulasi Virtual pada Pendekatan Pembelajaran Konseptual Interaktif dalam Meningkatkan Pemahaman Konsep dan Meminimalkan Miskonsepsi. Laporan Penelitian Hibah Kompetitif UPI. Bandung. FMIPA UPI; 1-13

Suhandi, A dan Wibowo, F.C.(2012). Pendekatan Multirepresentasi dalam Pembelajaran Usaha-Energi dan Dampak terhadap Pemahaman Konsep Mahasiswa. Jurnal Pendidikan Fisika Indonesia. 8(1)

Suhendi, H.Y., Kaniawati, I., dan Maknun, J. (2014). Peningkatan Pemahaman Konsep dan Profil Miskonsepsi Siswa Berdasarkan Hasil Diagnosis Menggunakan Pembelajaran ECIRR Berbantuan Simulasi Virtual dengan Instrumen Three-Tier Test. Prosiding Matematics and Sciences Forums 2014.

Suratman. (2010). Pembelajaran Berbasis Masalah Menggunakan Simulasi Virtual untuk Meningkatkan Pemahaman Konsep dan Keterampilan Proses Sain Siswa SMP pada Konsep Tekanan. Thesis Sekolah Pascasarjana Universitas Pendidikan Indonesia. Bandung.

Tan, D,. Khang, G, N., \& Sai C.L. (1997). Development of a Two-tier multiple Choiche Diagnostic Instrumen to Determine A-Level Students' Understanding of Ionisation Energy. National Institute Of Education, Nanyang Technological University, Taiwan.

Temel, S. (2014). The Effects of Problem Solving on Pre-service Teachers' Critical Thingking Dispositions and Perceptions of Problem-solving Ability. Jurnal South African Journal of Education. 34(1); 1-20

Watson, J., Prieto, T., dan Dillon, J.S. (1997). Concistency af Student's Explanationa about Combustion. Jurnal Science Education. 81; 425-443.

Wenning, Carl.J.(2008). Dealing more Effectively with Alternative Conceptions in Science. Journal of Physics Teacher Education Online. 5(1); 11-19

Widodo, P. (2000). Penggunaan Media Video Kaset Sebagai Alat Bantu Dalam Sistem Pembelajaran Modul untuk Meningkatkan Prestasi Belajar Fisika Siswa. Thesis 
Sekolah Pascasarjana Universitas Pendidikan Indonesia. Bandung

Yeo, S \& Marjan Z. (2001). Introductory Thermal Concept Evaluation : Assessing Student's Understanding. Journal The Physics Teacher. 39; 496-504 